Article

\title{
Food Sovereignty and Food Security: Livelihood Strategies Pursued by Farmers during the Maize Monoculture Boom in Northern Thailand
}

\author{
Sayamol Charoenratana ${ }^{1}$, Cholnapa Anukul 1,2,*(D) and Peter M. Rosset $^{\text {3,4,5 }}$ \\ 1 Human Security and Equity Research Unit, Chulalongkorn University Social Research Institute (CUSRI), \\ Chulalongkorn University, Bangkok 10330, Thailand; sayamol.c@chula.ac.th \\ 2 Foundation for Just Society Network, Bangkok 10330, Thailand \\ 3 Departamento de Agricultura, Sociedad y Ambiente, El Colegio de la Frontera Sur (ECOSUR), \\ San Cristóbal de las Casas 29200, Mexico; prosset@ecosur.mx \\ 4 Chulalongkorn University Social Research Institute (CUSRI), Chulalongkorn University, \\ Bangkok 10330, Thailand \\ 5 Programa de Pós-Graduação em Sociologia (PPGS), Universidade Estadual do Ceará (UECE), \\ Fortaleza 60175-100, Brazil \\ * Correspondence: cholnapa@gmail.com; Tel.: +66-2-218-7392
}

Citation: Charoenratana, S.; Anukul, C.; Rosset, P.M. Food Sovereignty and Food Security: Livelihood Strategies Pursued by Farmers during the Maize Monoculture Boom in Northern Thailand. Sustainability 2021, 13, 9821. https://doi.org/10.3390/su13179821

Academic Editor: Hossein Azadi

Received: 7 July 2021

Accepted: 27 August 2021

Published: 1 September 2021

Publisher's Note: MDPI stays neutral with regard to jurisdictional claims in published maps and institutional affiliations.

Copyright: (c) 2021 by the authors. Licensee MDPI, Basel, Switzerland. This article is an open access article distributed under the terms and conditions of the Creative Commons Attribution (CC BY) license (https:// creativecommons.org/licenses/by/ $4.0 /)$.

\begin{abstract}
Northern Thailand is the center of a number of controversies surrounding changing cropping patterns, in particular related to deforestation driven by the expansion of maize monocropping by peasant farmers. Growing demand for maize by the global livestock industry has driven the conversion of land from forest and/or shifting cultivation to chemical-intensive maize, with associated environmental (i.e., forest encroachment and annual burning of fields) and social (i.e., farmer indebtedness) problems. Over the years, some of the same farmers have been exposed to 'alternative development' programs and projects, initially motivated by pressure to substitute for illegal crops and more recently by concerns over deforestation and particulate matter air pollution from the burning of crop residues. This scenario is made more heterogeneous by a variety of land tenure situations and greater or lesser degrees of community control over land and forest. Faced with varied situations, peasant families can pursue different livelihood strategies, particularly in reference to the degree to which their production is market oriented. Based on surveys and interviews with farmers in Nan and Chiang Mai provinces, over a range of the aforementioned circumstances, we contrast families who pursue what we define as food security (cash cropping to earn money to buy food), food sovereignty (primarily production for self-provisioning) or mixed (a combination of both) strategies. In terms of indicators such as indebtedness, we find greater benefits from the food sovereignty and mixed strategies, though we also find that these are limited by security of land tenure issues, as well as by the degree to which community management of resources is or is not present.
\end{abstract}

Keywords: food security; food sovereignty; sustainability; land scarcity; community right; Thailand

\section{Introduction}

Northern Thailand is in the grips of a decades-long expansion of monocropped maize produced by peasants and small farmers to supply the global livestock feed complex, which is strongly rooted in Thailand. As maize monoculture has come to dominate both landscapes and the economic activity by farmers, a number of social (i.e., farmer indebtedness and food insecurity) and environmental (i.e., forest clearing, seasonable burning, etc.) concerns have emerged. For example, peasants burning their fields are blamed for serious particulate matter haze pollution in cities, but often claim this is decontextualized and presented with no explanation of how livestock agribusiness on a global scale is the central driver of these dynamics. 
There have been diverse responses to this emerging crisis, ranging from the strategies pursued by peasant families themselves to the 'alternative development' projects offered by diverse institutions, in order to ostensibly address issues ranging from deforestation and burning to farmer livelihoods. This provides the rich background and context, with farmers under varied circumstances of land tenure, market engagement, etc., for our analysis presented below of farmer strategies under these circumstances. In this paper we report on interviews and surveys applied primarily to peasant families with varied engagement in maize monocropping and in development projects, in Nan and Chiang Mai provinces in Northern Thailand. We sought to compare and contrast families who pursue strategies more based on placing self-sufficiency before the market, which we define below as food sovereignty and mixed strategies, versus an exclusive focus on production for the market, to earn income to buy food, which we call a food security strategy.

\subsection{Upland Maize in Northern Thailand and Myanmar}

Maize was first introduced in Thailand just after World War I in an experimental plot. Shortly after World War II, maize cultivation became more common for household production of livestock feed. After the 1st National Economic Development Plan (NEDP) (1961-1966) was launched in 1961, the Thai government promoted transportation network improvement, international trade, and more specifically, the research and development of new hybrid maize seed varieties [1]. The development and growth of a large commercial livestock feed industry [2] demanding ever growing quantities of maize led to a boom in maize in the 1980s, which in the first two decades of the 21st century has led to a geographical boom in the mountainous northern provinces of Thailand under which small farmers have increasingly been induced to abandon traditional swidden agricultural practice and shift into chemical- and credit-intensive monocropping of maize on sloping lands to sell at purchasing stations set up by representatives of the livestock feed industry, particularly the Charoen Pokphand (CP) Group and the Betagro Group. Driven to expand production by price incentives and debt, farmers increasingly encroached on forested areas and engaged in the environmentally questionable practices of annual burning of maize fields, leading to environmental problems at a regional level of deforestation, particulate matter air pollution, soil erosion, and loss of soil fertility, compensated for by increasing applications of chemical fertilizers. Many authors point to the unsustainable nature of the Northern maize monocrop boom, as soil erosion and fertility loss worsen and farmer indebtedness increases [3,4]; while the same phenomena can be seen in nearby Shan province of neighboring Myanmar [5].

Only seven private companies account for the largest market share of food manufacturing and livestock market in Thailand. The country's agrifood supply chain is connected and led by Charoen Pokphand Group, Betagro Group, Saha Farms Company, Cargill Thailand, Thai Foods Group, General Food Poultry Thai, and Laemthong Corporation Group. In total, $90 \%$ of chicken meat produced in Thailand belongs to them [6]. Among these, according to the Market Research Reports, CP that has diverse businesses consisting of seeds, fertilizer, animal feed, and agribusiness is currently the largest animal feed manufacturer in the world [7]. Although these private companies have dominant power over the market [8], they are ironically not considered as 'market dominant' under the Trade Competition Act B.E. 2542. This shows their power to be over the politics and government as well.

When Myanmar agriculture attracted many foreign investors, CP became one of the biggest foreign companies there, contributing to maize plantation and livestock processing plant. A study in 2015 indicated that over $80 \%$ of the maize seed market belongs to CP [5]. The majority of maize was exported to China for chicken feed purpose. The incentive of a large company caused cultivation shift in Myanmar, from traditional upland subsistence farming to commercialized monocropping for export.

The Royal Project Foundation (RPF) was founded in 1969 with the Crown Property Bureau of King Bhumibol Adulyadej as the key patron and focused on quality of life improvement for hill tribes and on forest restoration. At a time of heavy pressure from the 
United States, its main goal was to create community and livelihood development projects to eliminate opium production in the highland area of Thailand by providing resources for agrarian change as well as irrigation systems. For almost half a century, it has claimed many humanitarian success stories and invested its effort on community participation and empowerment of hill tribes and ethnic minorities [9]. Nevertheless, the role of the RPF has been to work in the context of governmental conservation policy, which has often been in conflict with community rights to land and forest [10-13]. The governmental appropriation of highland forests has been justified by portraying hill tribes as the destroyers of the forest [14], and the RPF played the role as forest guardian, attempting to sedentarize hill tribes to reduce their use of forested lands [15]. While the RPF provided support to hill tribes by buying their organic products, they remain poor and continue to face discrimination as ethnic minorities. To further confuse the situation, some hill tribes exploit other migrants as farm workers and, due to the labor requirements of organic farming, with intensive manual labor and low wages [16]. The RPF has more recently oriented its so-called 'Model Projects' to address some of the issues related to the expansion of maize monocropping and related deforestation.

\subsection{The Debate between Food Security and Food Sovereignty}

The term 'food security' was first introduced in 1974 at the World Food Conference, and it began from a food supply perspective, in terms of assuring food availability and price stability. In 1983, the Food and Agriculture Organization (FAO) added a food access dimension. Sen's theory of famine (1981) showed the impact of individual entitlements on food access and noted the temporal dynamic of food insecurity [17], introduced in the World Bank Report on Poverty and Hunger [18]. In this well-known report, two categories of food insecurity were described. While chronic food insecurity was caused by ongoing structural poverty, transitory food insecurity existing in a specific time was related to natural disasters, economic breakdowns, or conflicts. The concepts of vulnerability and risk management were incorporated, especially in emergency contexts. As a result, food insecurity was perceived as a social and political construct [19]. Since then, the food security concept has been dominant in policy spaces and has evolved accordingly [20].

In 1948, right-to-food concept first recognized in the UN Declaration of Human Rights was adopted in the World Food Summit. Hence, ethical and rights based approaches were integrated with food security. Moreover, the most widely accepted food security definition as introduced by World Food Summit in 1996 is: "at the individual, household, national, regional and global levels [food security is achieved] when all people, at all times, have physical and economic access to sufficient, safe and nutritious food to meet their dietary needs and food preferences for an active and healthy life" [21]. This definition focuses on the demand side, on food consumption, and the access of vulnerable people. It highlights four dimensions of food security, which are food availability, nutritional quality, utilization, and stability [22]. Food availability highlights the role of production, distribution, and exchange in providing reliable and consistent sources of nutritious food in sufficient quantities [23]. Food access focuses on individual exchange entitlements in terms of food affordability and allocation. Utilization emphasizes people's ability to choose, prepare, and distribute food to reach nutritional well-being. Stability assures food availability and access for all people at all times (Figure 1). Additionally, this concept includes enough food, good food, healthy food and culturally appropriate food. In general, people could access food supply through four channels, which are agriculture production, hunting and gathering, purchasing, and sharing [24]. Therefore, each population group with different food access channels would achieve food security in a different way.

Among the 17 Sustainable Development Goals (SDGs) established by the United Nations (UN) in 2015, 'Zero Hunger' is SDG 2, to be achieved by 2030, whose purposes are ending hunger, achieving food security and improved nutrition, and promoting sustainable agriculture. Its policy indicators consist of 100\% access to adequate food all year round, all food systems being sustainable, and a 100\% increase in smallholder productivity 
and income, which are responsive to the food security concept. These demonstrate the increasing importance of the food security issue in the context of climate change, which exerts unequal impacts among population groups, where landless or small-scale farmers are among those most affected [23,25-27].

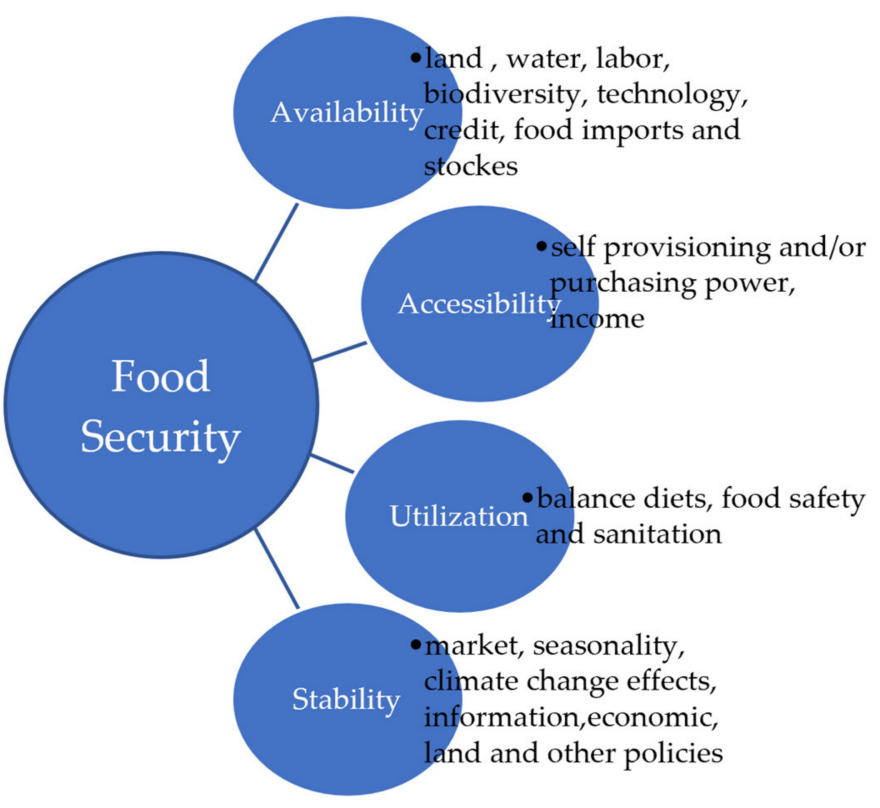

Figure 1. Four dimensions of food security concept.

In the past, the majority of the food produced by Asian rural farmers was consumed in their households, while the surplus was sold in the market or exchanged locally. Since monoculture farming has been promoted, along with increases in scale, food has become a commodity for mass consumption, increasingly being sold in the market rather than being consumed in the household. Maize, cassava, sugarcane, beans, coffee, cabbage, etc., have become 'cash crops', instead of peasant foods. Instead of household consumption demand, contemporary agriculture has become predominantly dependent on price signals from the market. Monoculture farming has transformed agriculture into a business investment, where production costs are affected by increasing prices of chemicals for both fertilizers and pesticides, labor wage costs, soil degradation, water stress, etc.

In response to market demand for cash crops, monoculture expansion has caused deforestation, even on sloping land and high mountain areas. Hence, water source have been transformed into "bald" mountains (Figure 2). Soil and water resources have been contaminated by the chemical use on monocultures. Severe forest fires and haze from the burning of crop residues have been condemned. Furthermore, climate change has produced associated declines in agricultural productivity [28-30], which affects farmers income. Lower income farmers are at risk for poverty, because when they plant a monoculture for the market, they often cannot buy sufficient quantities of food of appropriate quality. The driving force behind monoculture expansion by farmers is the possibility of cash income [24], yet the reality is that this makes small-scale farmers more vulnerable to food insecurity.

There is an associated relationship between food security and land security, which is increasingly noticeable [24,31,32]. Monoculture expansion in conservation land is aggravating agricultural land scarcity and generating land tenure rights conflicts while increasing food insecurity among farmer households, especially in sloping land or high mountain areas in northern Thailand. 


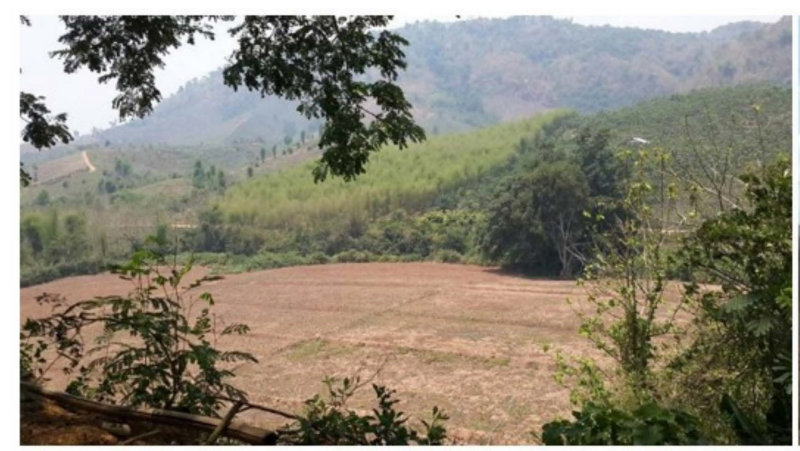

(a)

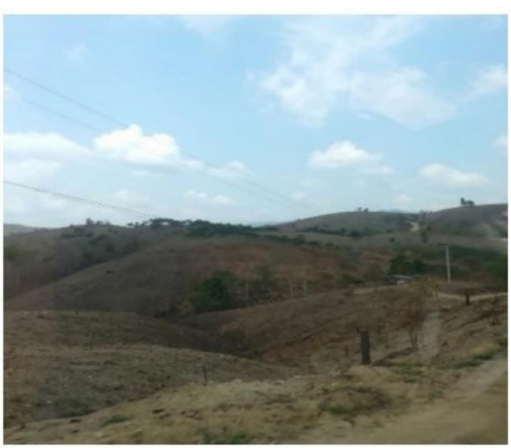

(b)

Figure 2. Rice field and agriculture practice in high mountain in Pua District, Nan Province (a); bald mountain caused by agriculture expansion in Mae Chaem District, Chiang Mai Province (b).

All of these factors feed into the reasons why the global peasant movement, La Via Campesina, and allies including many academics, have for many years critiqued the food security paradigm while putting forth food sovereignty as an alternative [33-35]. While under food security, it is expected that farmers can focus on cash crops and use the resulting income to cover their basic needs including food, the reality is that depending on an income source that can drop dramatically at any time due to climatic factors, pests and diseases, market fluctuations, and other factors, does not provide any sort of real security in terms of meeting food needs. By contrast, following a food sovereignty strategy would suggest that farmers should seek to focus on first meeting their critical food needs through their own production of subsistence crops and livestock and only then use excess capacity to produce for the market, thus insulating their true food security from many kinds of external shocks. It should also be evident that the success of any of these strategies is critically dependent on security of land tenure.

The aim of this study, then is to compare farmers following these distinct strategies in the contemporary context of expansion of maize monoculture in Northern Thailand. To this end, we evaluated farm families in the following three categories of livelihood strategies:

(1) Food sovereignty strategy: cultivate a variety of crops for adequate household consumption and be able to sell a small surplus in the market;

(2) Food security strategy: cultivate nonhousehold-use crops, such as maize monoculture, and sell them to purchase both rice and other food for household consumption.

(3) Mixed strategy: cultivate food crops such as rice for self-consumption and grow cash crops to sell and purchase other food items from the market with money earned from their sale.

Our working hypothesis was that the food sovereignty and mixed strategies would enhance real food security among farmers with limited access to land.

\section{Materials and Methods}

The fieldwork for this study was carried out in two phases. The first phase of the study focused on the linkage between land tenure security and food security and food sovereignty among rural farmer households, and the second phase emphasized an examination of security of land tenure interventions to ensure the food security of farmer families. Given these study purposes, a mixed methods design was applied.

The initial criteria for the selection of the study area were: (1) over $50 \%$ of the area forest area; (2) there exist land conflicts related to forests, deforestation, and the lack of land tenure rights; (3) there are negative agricultural impacts including smoke and haze, soil erosion, and agrochemical contamination; (4) agriculture land is located nearby or in the forest areas.

Nan Province and Chiang Mai Province were selected according to these criteria (Figure 3). In order to study the association between land tenure rights, food security and food sovereignty in rural areas, the first phase of the study was conducted in Nan Province. 
Since Chiang Mai Province has implemented land tenure security interventions through the Mae Chaem Model and the Mae Chaem Model Plus to attempt to resolve the land conflicts in the area, Chiang Mai was selected as area of study for the second phase.

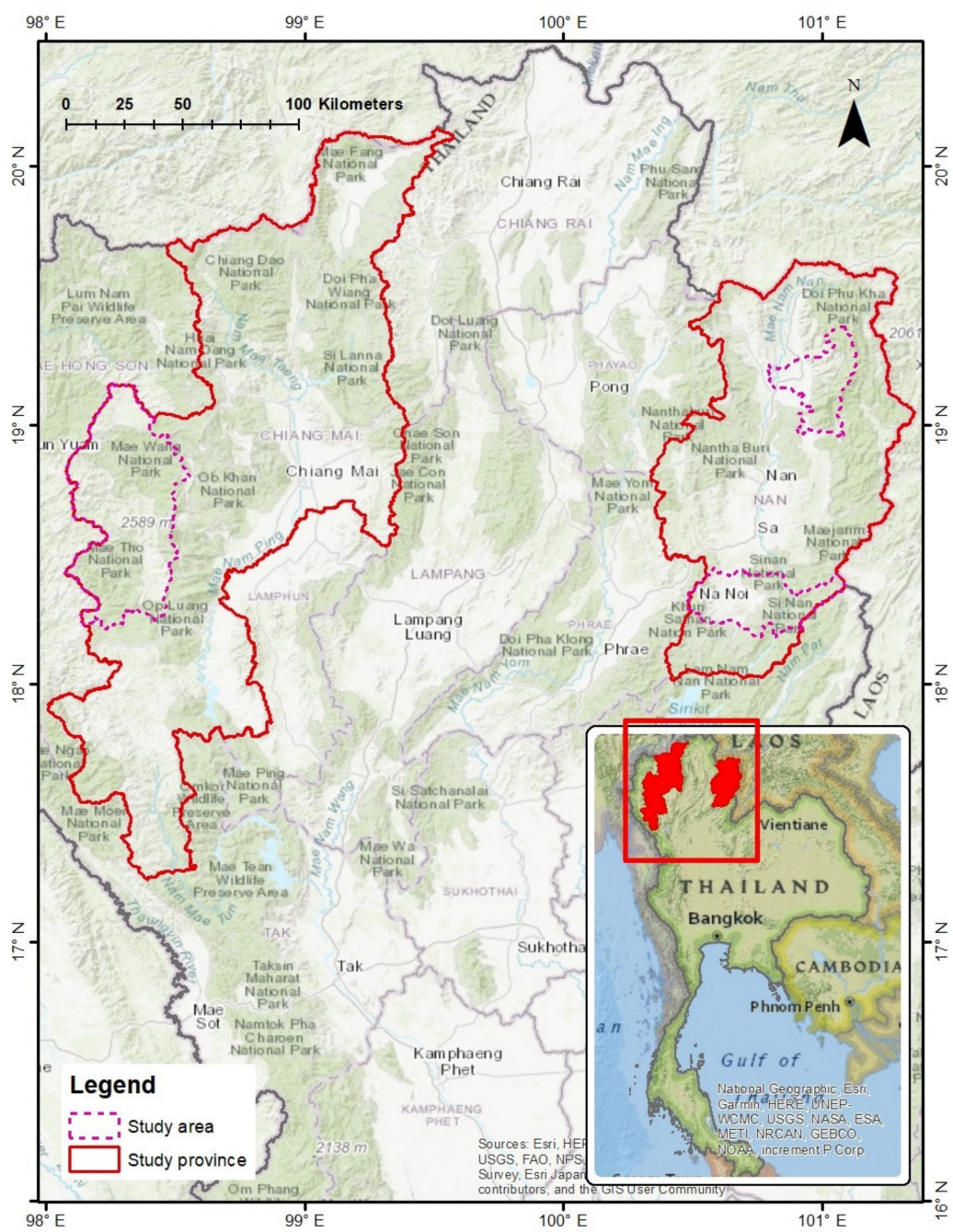

Figure 3. Study sites in Nan Province and Chiang Mai Province.

In Nan Province, the research participants consisted of peasant farmer households in the Bua Yai Subdistrict of the Na Noi District and the Sathan Subdistrict of Pua District. In Chiang Mai Province, the research participants were government officials, NGOs, and farmers in the Chang Khoeng Subdistrict of Mae Chaem District. Before the beginning of the research, informed consent was obtained from each research participant verbally. The personal information and individual identity were kept confidential. Both digital and paperbased research data collection were put in safekeeping. Only the project researchers have access to those data. Within two years after the project closes, the data will be destroyed.

The fieldwork was conducted as follows:

1st Phase: Two subdistricts in Nan Province were purposively designated as study areas, since they exhibit a higher amount of deforestation issues than other areas. Those were Bua Yai Subdistrict, Na Noi District, and Sathan Subdistrict, Pua District. All 8 villages of Bua Yai Subdistrict were chosen, while 11 of 13 villages of Sathan Subdistrict were selected, since the other two villages had no deforestation issues. Purposive sampling data of 426 household respondents were collected, among which 205 household respondents were residents of 8 villages in Bua Yai Subdistrict and 221 household respondents were residents of 11 villages in Sathan Subdistrict (Table 1). 
Table 1. Study areas in Nan Province.

\begin{tabular}{|c|c|c|c|c|c|}
\hline & District & Nr. & Village & Frequency & Percentage \\
\hline \multirow{10}{*}{1.} & \multirow{9}{*}{ Na Noi } & & Bua Yai Subdistrict & & \\
\hline & & 1 & Ban Oi Village & 29 & 14.1 \\
\hline & & 2 & Ban Mai Mongkol Village & 25 & 12.2 \\
\hline & & 3 & Ban Na Nae Village & 30 & 14.6 \\
\hline & & 4 & Ban Thap Maan Village & 31 & 15.1 \\
\hline & & 5 & Ban Na Kai Village & 25 & 12.2 \\
\hline & & 6 & Ban Ton Muang Village & 17 & 8.3 \\
\hline & & 7 & Ban San Payom Village & 16 & 7.8 \\
\hline & & 8 & Ban Nong Ha Village & 32 & 15.6 \\
\hline & \multicolumn{3}{|c|}{ total } & 205 & 48.1 \\
\hline \multirow{14}{*}{2.} & \multirow{12}{*}{ Pua } & & Sathan Subdistrict & & \\
\hline & & 3 & Ban San Lhao Village & 21 & 9.5 \\
\hline & & 4 & Ban Don Sathan Village & 20 & 9.5 \\
\hline & & 5 & Ban Huai La Village & 21 & 9.5 \\
\hline & & 6 & Ban Na Fang Village & 21 & 9.5 \\
\hline & & 7 & Ban Pa Yeng Village & 21 & 9.5 \\
\hline & & 8 & Ban Mai Chai Charoen Village & 13 & 5.9 \\
\hline & & 9 & Ban Santi Sook Village & 21 & 9.5 \\
\hline & & 10 & Ban Porn Sawan Village & 22 & 10.0 \\
\hline & & 11 & Ban Ton Pueng Village & 20 & 9.0 \\
\hline & & 12 & Ban Don Sathon 1 Village & 21 & 9.5 \\
\hline & & 13 & Ban San 1 Village & 20 & 9.0 \\
\hline & \multicolumn{3}{|c|}{ total } & 221 & 51.0 \\
\hline & \multicolumn{3}{|c|}{ total } & 426 & 100.0 \\
\hline
\end{tabular}

2nd Phase: Ban Huai Rin Village, Chang Khoeng Subdistrict, Mae Chaem District, Chiang Mai Province was designated as the study area, since its residents engaged with the 'Mae Chaem Model' project and the 'Mae Chaem Model Plus' project. Some of them have applied so-called 'good agricultural practices' (GAP) in their land. Qualitative data were collected from 15 in-depth interviews and 2 focus group discussions. In order to have a holistic view of land security interventions affecting food security, 6 local authorities, 3 NGOs, and 6 residents of Ban Huai Rin Village were interviewed in-depth. The participants of the first focus group discussions were local authorities involved with the Mae Chaem Model and the Mae Chaem Model Plus projects. In the second group discussion, 15 residents of Ban Huai Rin Village participated.

\section{Results}

We demonstrates our findings by: (1) a shift in cropping patterns; (2) security of livelihood and food security; (3) association of land tenure and food security; and (4) right to access and usage of forest. In each issue, the results from Nan Province and Chiang Mai province are described one after the other.

\subsection{Cultivation Shift}

\subsubsection{Nan Province}

Maize plantation began initially in both Pua District and Na Noi District of Nan Province in 1973, after the government forest concession policy was launched [36]. The interviewees informed us that an initial purpose of the forest concession was part of the counter-insurgency strategy to defeat communist party guerrillas. The forest concessions led to deforestation and lower density of trees, which revealed guerilla hideouts. However, the more commercial cultivation maize agriculture began around 2000. A decade later, the maize area had expanded enormously, as the Thai government offered price insurance for maize in 2009-2010. It was believed that maize cultivation would offer a fast return on investment with low risk. Although the corporations would eventually have relatively 
little presence in the districts, local middlemen for re-selling to them have been providing a variety of in-kind credit for seeds, fertilizer, and pesticides. Hence, the expansion of monocrop production in Nan Province was stimulated first for political reasons and was given a commercial purpose more recently.

\subsubsection{Chiang Mai Province}

In the early 1960s, in accordance with the 1st NEDP (1961-1966), Mae Chaem District, Chiang Mai Province, began commercial farming; the scale of which has unceasingly expanded ever since. Initially, maize was planted along with other cash crops such as soybeans in flat land, especially in Long Pong Village. Since Mae Chaem District is located in an upland area, the Mae Chaem Watershed Development project was provided to provide irrigation for commercial farming. However, the project was a failure and was shut down in 1987. After the extreme draught between 1992-1993 causing production problems and coinciding with price swings, the flat land was transformed to onion, garlic, and cabbage, whose products had higher prices. In parallel, maize agriculture was displaced to upland areas. Deforestation accelerated after 1999 as the Maize Seed Company set up operations in the district and promoted maize plantation with crop price insurance on 791 acres in Ban Sam Sob Village and Kong Khaek Village [37]. Since then, maize plantation has been incessantly growing and became the main economic cash crop in Mae Chaem District [38], peaking and beginning a decline in 2017.

\subsection{Characterization of Livelihood and Food Security \\ 3.2.1. Nan Province}

The average number of household respondents in Na Noi and Pua District, Nan Province was three. Most of them were male (61\%), with an average age of 53 years old. In total, $77.5 \%$ of all respondents in Nan Province were mid-career workers older than 30 years old. The average age of Na Noi District's respondents is 5 years younger than Pua's.

Overall, most of respondents (79.1\%) thought that their income was insufficient to make a living (Table 2); among whom, 51.6\% said that their daily living expenses were high, and $9.2 \%$ explained that agricultural production costs and investment were the causes. Among the respondents who thought that their income was sufficient $(19.7 \%), 50 \%$ noted that they spend within the limits of what they have, and 25\% commented that they have regular income from off-farm employment.

Table 2. Self-evaluation of income sufficiency level in Na Noi and Pua District, Nan Province.

\begin{tabular}{ccccccc}
\hline \multirow{2}{*}{ Question } & \multicolumn{2}{c}{ Na Noi } & \multicolumn{2}{c}{ Pua } & \multicolumn{2}{c}{ Total } \\
\cline { 2 - 7 } & Frequency & \% & Frequency & $\%$ & Frequency & $\%$ \\
\hline \multirow{3}{*}{ Insufficient } & 192 & Do you think you have sufficient income? \\
Sufficient & 12 & 7.93 & 145 & 6.65 & 337 & 1.79 \\
No reply & 1 & 9.5 & 72 & 6.32 & 84 & 7.19 \\
Total & 205 & 5.0 & 4 & 8.1 & 5 & 1.2 \\
\hline
\end{tabular}

By and large, the majority of respondents in Nan Province were farmers with low annual-income levels, whose average was 4236 USD per household. Here, 89.2\% of respondents in Nan had debts, both formal and informal, with an average debt burden of 8556 USD per household (Table 3). Hence, the average debt is two times higher than average annual income, a fact which casts doubt on future livelihood security.

While farmers in Na Noi District had a higher income than farmers in Pua District, Na Noi farmers had larger debts than Pua farmers. The average annual income of respondents in Na Noi District was 5022 USD per household, which was 31\% higher than Pua's (3477 USD). While the lowest annual income of Na Noi respondent was 598 USD, the lowest annual income of a Pua respondent was 180 USD. Nevertheless, the average debt of Na Noi respondents was 10,761 USD, while Pua respondents had 5940 USD of 
average debt, which was $45 \%$ less. Pua District also had twenty times fewer debtors than Na Noi District. Additionally, Na Noi respondents had three times more informal debt than formal debt.

Table 3. Household income per year and household debts in Na Noi and Pua District, Nan Province.

\begin{tabular}{|c|c|c|c|c|c|c|}
\hline \multirow{2}{*}{$\begin{array}{l}\text { Household } \\
\text { Income/Year }\end{array}$} & \multicolumn{2}{|c|}{ Na Noi } & \multicolumn{2}{|c|}{ Pua } & \multicolumn{2}{|c|}{ Total } \\
\hline & Frequency & $\%$ & Frequency & $\%$ & Frequency & $\%$ \\
\hline$\leq \$ 598$ & 3 & 1.5 & 10 & 4.5 & 13 & 3.1 \\
\hline \$599-\$1196 & 16 & 7.8 & 34 & 15.4 & 50 & 11.7 \\
\hline$\$ 1197-\$ 1795$ & 24 & 11.3 & 25 & 11.7 & 49 & 11.5 \\
\hline$\$ 1796-\$ 2393$ & 13 & 6.3 & 20 & 9.0 & 33 & 7.7 \\
\hline \$2394-\$2991 & 26 & 41.9 & 36 & 16.3 & 62 & 14.6 \\
\hline \$2992-\$8974 & 102 & 49.8 & 73 & 33.0 & 175 & 41.1 \\
\hline$\$ 8975-\$ 14,956$ & 12 & 5.9 & 9 & 4.1 & 21 & 4.9 \\
\hline$\geq \$ 14,957$ & 9 & 4.4 & 14 & 6.3 & 23 & 5.4 \\
\hline Total & 205 & 100 & 221 & 100 & 426 & 100 \\
\hline Average & \multicolumn{2}{|c|}{$\$ 5022$} & \multicolumn{2}{|c|}{$\$ 3477$} & \multicolumn{2}{|c|}{$\$ 4236$} \\
\hline Lowest & \multicolumn{2}{|c|}{$\$ 598$} & \multicolumn{2}{|c|}{$\$ 180$} & \multicolumn{2}{|c|}{$\$ 180$} \\
\hline Highest & \multicolumn{2}{|c|}{$\$ 23,930$} & \multicolumn{2}{|c|}{$\$ 17,947$} & \multicolumn{2}{|c|}{$\$ 23,930$} \\
\hline \multicolumn{7}{|l|}{ Household Debt } \\
\hline Debts (\%) & \multicolumn{2}{|c|}{99.0} & \multicolumn{2}{|c|}{80.1} & \multicolumn{2}{|c|}{89.2} \\
\hline Average & \multicolumn{2}{|c|}{$\$ 10,761$} & \multicolumn{2}{|c|}{$\$ 5940$} & \multicolumn{2}{|c|}{$\$ 8556$} \\
\hline Lowest & \multicolumn{2}{|c|}{$\$ 150$} & \multicolumn{2}{|c|}{$\$ 60$} & \multicolumn{2}{|c|}{$\$ 60$} \\
\hline Highest & \multicolumn{2}{|c|}{$\$ 44,869$} & \multicolumn{2}{|c|}{$\$ 59,825$} & \multicolumn{2}{|c|}{$\$ 59,825$} \\
\hline
\end{tabular}

In terms of livelihood security of the families in the community (Table 4), we divide the results as follows:

(a) Economic Security, Food Security, and Land Security Dimensions

The survey results indicate that in the previous year, Nan respondents had partial economic security including income, jobs, and saving security dimensions. Nan respondents had partial income security (2.34), because of reduced agricultural productivity and crop prices along with high investment costs. Their jobs were viewed as partly secure (2.44), since most of them were farmers with limitations of resources such as land and investment capital. Because they earned less, their ability for saving at least $10 \%$ of annual income was affected as well. Their savings were only partly secure (2.29).

From food security perspectives, however, Nan respondents felt that they had experienced food security in the last year (2.78). They rated their capability to access food as secure (2.57), because apart from rice cultivating to make a living they could gather food ingredients from the community forest, whose quantities were enough for their household demand. Still, household respondents with smaller land sizes struggled with less rice and other agricultural products.

Meanwhile, Nan respondents perceived that their land was secure. They regarded their ability to make a decision on planting as secure (2.82). Although governmental or private sectors had promoted a variety of new crops, farmers had the freedom to make their own decision. In addition, other residents, who were not landowners, could choose their own job without restrictions. Nan respondents considered that they had enough cultivated land (2.53). Even though part of their land holdings were illegal, the land size was large enough for appropriate quantities of agricultural products.

(b) Housing Security and Health Security Dimensions

Nan respondents perceived that their housing was good for their family (2.98). Most of them had their own house. A minimum standard housing was either renting a house or 
living with relatives. They evaluated their family member health as secure (3.38), because only mild sickness or minor symptoms were presented such as a cold.

Table 4. Self-evaluation of livelihood and family security levels in the previous years.

\begin{tabular}{|c|c|c|c|c|c|c|c|c|}
\hline Security of Life and Family & $\begin{array}{c}\text { Not } \\
\text { Secure } \\
(\%)\end{array}$ & $\begin{array}{c}\text { Partly } \\
\text { Secure } \\
(\%)\end{array}$ & $\begin{array}{c}\text { Secure } \\
(\%)\end{array}$ & $\begin{array}{l}\text { Moderate } \\
\text { Secure } \\
(\%)\end{array}$ & $\begin{array}{c}\text { Most } \\
\text { Secure } \\
(\%)\end{array}$ & $\bar{X}$ & S.D. & Average \\
\hline income for living expense & $\begin{array}{c}78 \\
(19.8)\end{array}$ & $\begin{array}{c}137 \\
(34.9)\end{array}$ & $\begin{array}{c}151 \\
(38.4)\end{array}$ & $\begin{array}{c}21 \\
(5.3)\end{array}$ & $\begin{array}{c}6 \\
(1.5)\end{array}$ & 2.34 & 0.906 & Partly Secure \\
\hline having a job & $\begin{array}{c}67 \\
(16.1)\end{array}$ & $\begin{array}{c}153 \\
(36.7)\end{array}$ & $\begin{array}{c}152 \\
(36.5)\end{array}$ & $\begin{array}{c}36 \\
(8.6)\end{array}$ & $\begin{array}{c}9 \\
(2.2)\end{array}$ & 2.44 & 0.934 & Partly Secure \\
\hline saving as $10 \%$ income & $\begin{array}{c}100 \\
(24.9)\end{array}$ & $\begin{array}{c}125 \\
(31.1)\end{array}$ & $\begin{array}{c}143 \\
(35.6)\end{array}$ & $\begin{array}{l}28 \\
(7.0)\end{array}$ & $\begin{array}{c}6 \\
(1.5)\end{array}$ & 2.29 & 0.967 & Partly Secure \\
\hline food consumption & $\begin{array}{c}30 \\
(7.1)\end{array}$ & $\begin{array}{l}106 \\
(25.1)\end{array}$ & $\begin{array}{c}241 \\
(57.1)\end{array}$ & $\begin{array}{c}33 \\
(7.8)\end{array}$ & $\begin{array}{c}12 \\
(2.8)\end{array}$ & 2.78 & 0.814 & Secure \\
\hline capability to access food & $\begin{array}{c}44 \\
(10.8)\end{array}$ & $\begin{array}{c}146 \\
(36.0)\end{array}$ & $\begin{array}{c}166 \\
(40.9)\end{array}$ & $\begin{array}{c}39 \\
(9.6)\end{array}$ & $\begin{array}{l}11 \\
(2.7)\end{array}$ & 2.57 & 0.904 & Secure \\
\hline capability to design own plantation & $\begin{array}{c}50 \\
(12.3)\end{array}$ & $\begin{array}{c}67 \\
(16.5)\end{array}$ & $\begin{array}{c}210 \\
(51.9)\end{array}$ & $\begin{array}{c}63 \\
(15.6))\end{array}$ & $\begin{array}{l}15 \\
(3.7)\end{array}$ & 2.82 & 0.965 & Secure \\
\hline enough land to cultivate & $\begin{array}{c}89 \\
(21.8)\end{array}$ & $\begin{array}{c}82 \\
(20.0)\end{array}$ & $\begin{array}{c}183 \\
(44.7)\end{array}$ & $\begin{array}{c}43 \\
(10.5)\end{array}$ & $\begin{array}{l}12 \\
(2.9)\end{array}$ & 2.53 & 1.036 & Secure \\
\hline good housing for family & $\begin{array}{c}41 \\
(9.7)\end{array}$ & $\begin{array}{c}66 \\
(15.6)\end{array}$ & $\begin{array}{c}203 \\
(48.1)\end{array}$ & $\begin{array}{c}85 \\
(20.1)\end{array}$ & $\begin{array}{c}27 \\
(6.4)\end{array}$ & 2.98 & 1.002 & Secure \\
\hline healthy family members & $\begin{array}{l}17 \\
(4.2)\end{array}$ & $\begin{array}{c}43 \\
(10.6)\end{array}$ & $\begin{array}{c}172 \\
(42.4)\end{array}$ & $\begin{array}{c}117 \\
(28.8)\end{array}$ & $\begin{array}{c}57 \\
(14.0)\end{array}$ & 3.38 & 0.991 & Secure \\
\hline participation in community resources & $\begin{array}{c}25 \\
(6.0)\end{array}$ & $\begin{array}{c}88 \\
(21.2)\end{array}$ & $\begin{array}{c}197 \\
(47.5)\end{array}$ & $\begin{array}{c}61 \\
(14.7)\end{array}$ & $\begin{array}{c}44 \\
(10.6)\end{array}$ & 3.03 & 1.013 & Secure \\
\hline living in good community & $\begin{array}{c}11 \\
(2.6)\end{array}$ & $\begin{array}{c}40 \\
(9.6)\end{array}$ & $\begin{array}{c}162 \\
(38.9)\end{array}$ & $\begin{array}{c}100 \\
(24.0)\end{array}$ & $\begin{array}{c}103 \\
(24.8)\end{array}$ & 3.59 & 1.045 & Moderately Secure \\
\hline Total & & & & & & 2.80 & 0.962 & Secure \\
\hline
\end{tabular}

\section{(c) Community Dimensions}

According to the participation level in community resource management, Nan respondents regarded this as being secure (3.03). The reasons given were that they could be involved in many decision-making processes, including the regulation of community forests and public hearings for community policies. What is more, they felt moderately secure in terms of living in a good community (3.59). Close relationships and strong support among community members were their robust social capital.

\subsubsection{Chiang Mai Province}

The interviewees of Ban Huai Rin Village, Chang Khoeng Subdistrict, Mae Chaem District, Chiang Mai Province reported that Ban Huai Rin villagers had less economic security, because of their low income and high accumulated debt. The main source of their income was maize monocropping, where either middlemen purchased the products from farmers directly at the plantation or they sold their maize at farm stores. Their expenses included agricultural investment, household expense, and child education in the city. The interview data demonstrate that farmers chose maize monocropping because it provides cash money to the household. Nevertheless, they had not calculated their overall profits and losses. From time to time, they obtained complementary income from selling garden vegetables, which helped cover their daily living expenses as did income from selling labor in diverse jobs such as construction workers.

From a food security perspective, interviewees informed us that Ban Huai Rin Village residents had rice plots for their own household consumption. In addition, vegetable plots were rotated in the limited rice fields (Figure 4a). The cultivated rice varieties were resistant to disease, suitable to the local conditions, and easy to care for, since most of them were local varieties. Even though upland rice was out of favor because of rainfall shortages, some farmers without flat land would cultivate the upland rice in the foothill or the upland area (Figures $4 \mathrm{~b}$ and $5 \mathrm{a}$ ). 


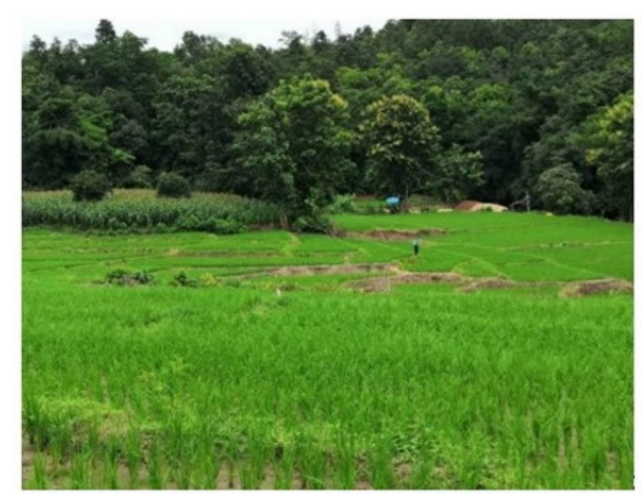

(a)

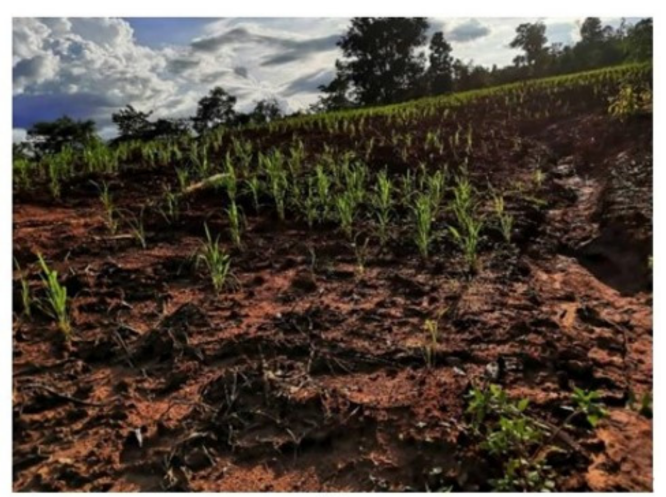

(b)

Figure 4. In Mae Chaem District, Chiang Mai Province: (a) rice plantation in plain area; (b) upland rice plantation in upland area.

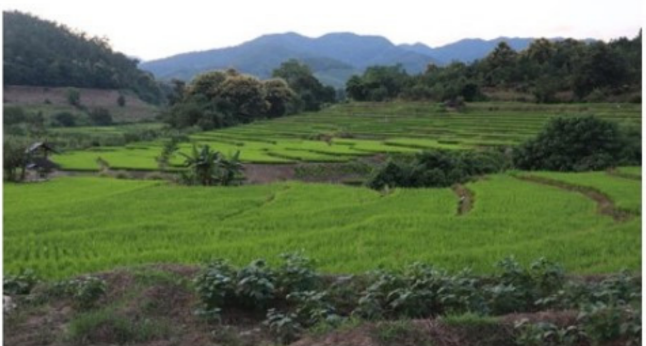

(a)

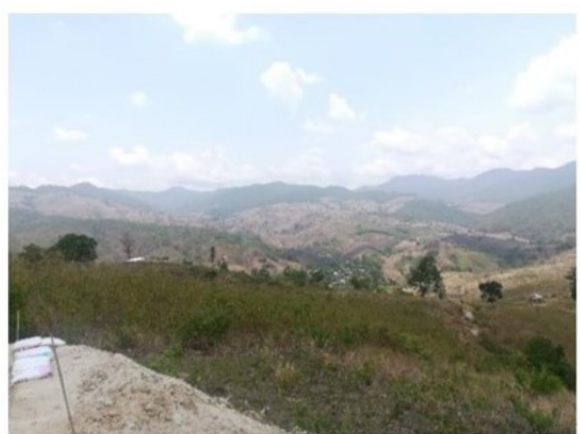

(b)

Figure 5. Rice terrace and maize cropping on the steep slope: (a) bald mountain with maize cropping (b) at Mae Chaem District, Chiang Mai Province.

In recent times, although farmers still cultivate rice for their own consumption, they have increasingly transformed other cultivated land from vegetables to maize monocropping, in part because the maize has a lower water demand and is feasible on sloping land. The maize yields are high enough to bring in more income than vegetables, whose harvesting factors are more complicated, given transportation time, spoilage, and low prices.

The governmental interviewees confirmed that maize cropping land expansion was the major force behind the higher rate of deforestation in Mae Chaem District as well as on the bald high mountain (Figure 5b).

From the community dimensions, Ban Huai Rin residents have a strong relationship in the community. Interviewees pointed out that all villagers know each other very well, because at least three generations of their families have lived on these lands, with collective experiences of mutual support in the village for a long time. In other words, they know who is who. The interview data confirm that Ban Huai Rin residents pay respect to several natural leaders, who have lived in the village for a long time. When there exist any problems, villagers deliberate all together. The Mae Chaem Model Project is an important case of participation, which Huai Rin villagers have decided to engage in to try to resolve economic and land issues in the community.

\subsection{Association of Land Tenure and Food Security \\ 3.3.1. Nan Province}

Nan Province is located in the remote Nan River valley, enclosed by forested high mountains and covering the area of $11,472 \mathrm{~km}^{2}$. As $85 \%$ of its area is a steep slope, only $15 \%$ is flat area suitable for housing and agriculture.

$\mathrm{Na}$ Noi District is situated in the southern part of Nan Province, covering the area of $1408 \mathrm{~km}^{2}$. Most of the area consists of sloping foothills and upland rather than flat lowland. 
On the other hand, Pua District is located in the northern part of Nan Province covering the area of $657 \mathrm{~km}^{2}$ with the mix of lowlands with flowing river and uplands. As a result, agricultural land tenure in Pua District is distributed across more varied topographical conditions. Pua farmers own various cultivated plots, including in both lowlands and uplands. Pua District has more lowland areas than Na Noi District; most of whose areas are upland. The majority of respondents of Na Noi District build their houses in the lowland area situated within the villages, and they farm in the upland areas located outside the villages.

In the survey results, respondents of Na Noi District possessed more plots of land than Pua respondents (Figure 6). The majority of Na Noi respondents owned four plots of land $(32.2 \%)$ and three plots of land $(31.2 \%)$, subsequently. Conversely, the majority of Pua respondents had two plots of land (45.7\%) and one plot of land (22.6), successively.

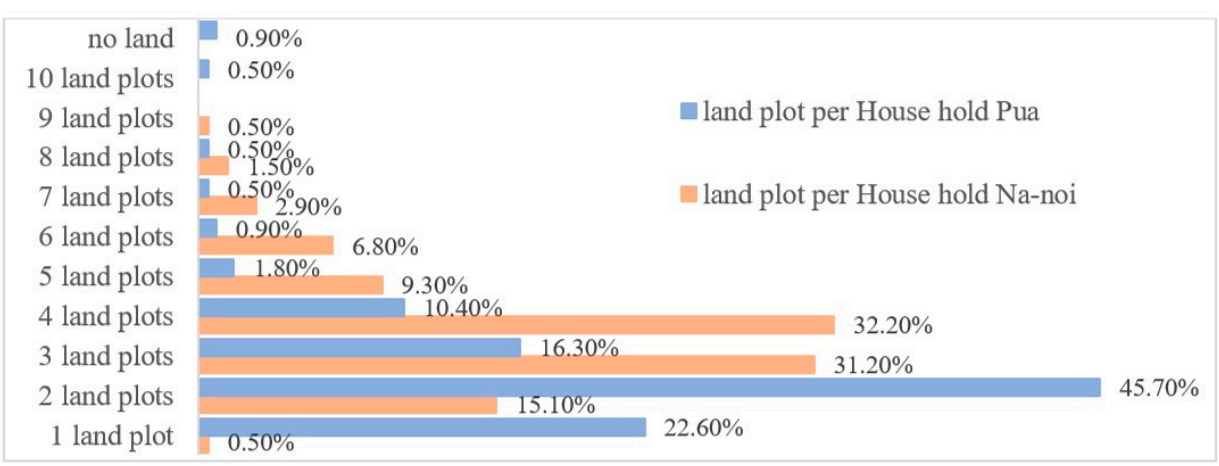

Figure 6. Number of land plots in possession of households in Na Noi District and Pua District, Nan Province.

The survey results also demonstrate that the land size owned by Na Noi respondents is larger than Pua's. The land sizes possessed by Na Noi respondents were 12-20 acres $(39.5 \%)$, above 20 acres $(28.3 \%)$, and $6-8$ acres $(10.2 \%)$. By contrast, the land sizes possessed by Pua respondents were $0.4-1.2$ acres (35.3\%), less than 0.4 acres (18.1\%), $1.2-2.0$ acres $(17.2 \%)$, and $2-4$ acres $(16.7 \%)$.

Still, although Pua residents have smaller and fewer plots of land than Na Noi residents, they have a higher level of land security. While $70.6 \%$ of Pua residents held land deeds, only $34.7 \%$ of $\mathrm{Na}$ Noi residents owned the legal right of land management.

\subsubsection{Chiang Mai Province}

Chiang Mai Province is the second largest province in Thailand located in Northern Thailand in the Mae Ping River basin. It covers an area of 20,107 $\mathrm{km}^{2}$, with an average of 1000 feet elevation surrounded by the Thai highlands. As $80 \%$ of its area is mountainous, the rest is plain land distributed along the river basin and foothills.

Mae Chaem District is situated in the western part of Chiang Mai Province, covering an area of $2687 \mathrm{~km}^{2}$. Since $73 \%$ of the area is forest with $58.66 \%$ watershed, it is regarded as the most fertile area. Most of Mae Chaem areas are mountains and foothills, and the governmental documents (deed, Nor Sor 3, Sor Por Kor 4-01, Agricultural Settlement) cover 9416 acres or only $1.40 \%$ of all land areas in Mae Chaem. However, the governmental interviewees reported that nowadays $25.60 \%$ of the land area (173,058 acres) is utilized. This indicates that there exist an overlapping of land use, land use without legal documents, and deforestation (Figure 7).

The land area of Mae Cham District is primarily devoted to maize monocropping. In this district, the total maize cultivated land $(67,213$ acres $)$ is 3.4 times larger than the area devoted to rice $(50,000)$. Many interview respondents were informed that the recent boom in maize monoculture was blamed as the main sources of three problems: (1) poverty among farmers, since the heavy debts of farmers are caused by the high costs of maize crop inputs; (2) dangerous haze particulate air pollution in Northern Thailand due to 
burning 90,000 tons of maize waste annually; (3) soil erosion, whose dregs fall into the upstream of Ping River and shorten the lifespan of Bhumibol Dam (the largest hydroelectric power plant).

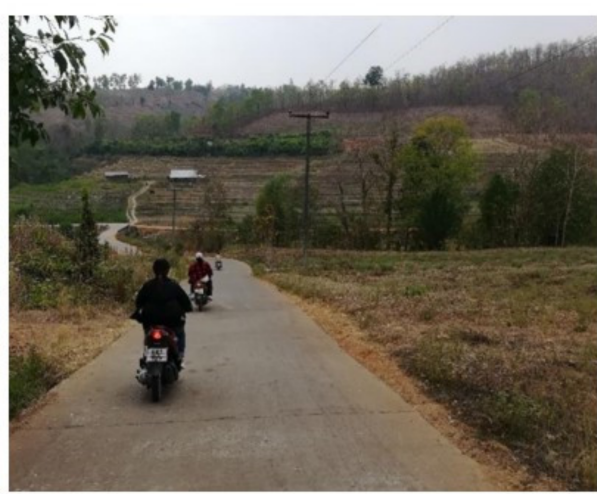

(a)

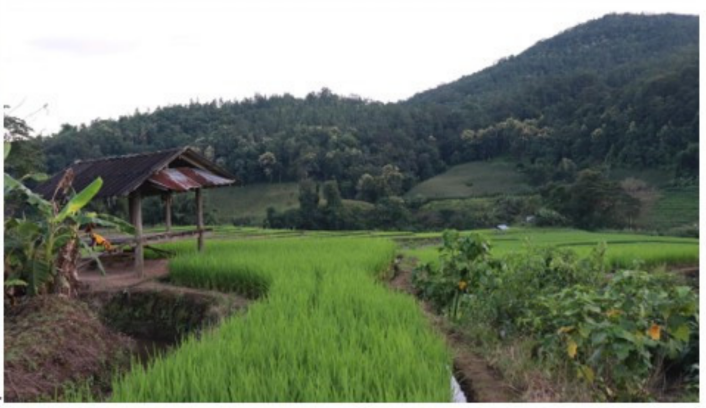

(b)

Figure 7. Agricultural land in Mae Chaem District (a) at mountain slope and (b) in plain area.

The interview results indicate that most of residents in Ban Huai Rin Village have their own rice plot, which is less than 2.4 acres for each household. As some households are landless, most of them are engaged in other occupations apart from agriculture such as being daily employed workers, construction workers, or vendors.

The interviewees inform that in 2002 the land tenure rights for cultivation were distributed to farmers in Ban Huai Rin Village. These so called 'community deeds' were issued by the 'National Land Policy Committee' according to the Agricultural Land Assignment Project. The 'community deeds' rights could not be traded but can be inherited by people in the same village or their own children. Since the villagers have lived for a long time in the area, each household could identify to whom the plots of lands belong. Thus, this represents a formalization of pre-existing land tenure arrangements. However, it was found that 10 households in Ban Huai Rin village possessed the land outside the village, far from the community deeds land and very close to the forest. Therefore, community deeds lands were not allocated to this group of villagers.

Since 2016, the Mae Chaem Model Project has been operating in Mae Chaem, as a policy response to forest fires and heavy haze from maize waste burning in the highland area [39-41]. The working plan for land management in Mae Chaem was introduced by the government with two main objectives within 5 years, which are as follows:

(1) The return of 98,077 acres of forest area to the government;

(2) The allocation of additional land and land rights to villagers as an extension of the previous project in 2002.

The redistributed land cannot be sold or transferred to others, but land inheritance is still allowed. Furthermore, the idea was to transition from monoculture to integrated farming with higher agricultural productivity, and farm marketing mechanisms and some funding would be provided.

To reduce burning, risk of forest fires, and haze in the remaining areas, maize waste such as corn stubble would be diminished with various techniques including tilling and adding fertilizer, processing waste into animal feed, making fuel pellets from cob and corn husks, encouraging schools to invent, use, or utilize them in numerous ways, and alternating burning days.

For the duration of project, forest fire and haze could be reduced with cooperation mechanisms at both local and provincial levels. The idea was to move from solving immediate crises to a more structural approach. However, the sustainability of the process toward structural change has been a major challenge. Hence, Mae Chaem Model Plus Project has recently been developed as the successor project and includes more participants 
such as the public sector, private sector, civil society, NGOs, academics, and residents in Mae Chaem District. The project aims to collectively solve the structural problems [39,40].

The interviewees described that the essential advantage of Mae Chaem Model Plus Project is conflict resolution between the government and villagers. The design is based on a so-called 'win-win strategy' [41] that should allow villagers to have more land-use rights and the government to preserve more forest area. The community deed assures that farmers have the rights to land use for making a living without fear of being evicted later and gives farmers the feeling of land security that would translate into support for governmental policy, based on a community mechanism to monitor the forest and practice active conservation.

\subsection{Right to Access and Usage of Forest}

\subsubsection{Nan Province}

As the terrains of Na Noi and Pua are made up of slopes and mountains, they are abundant with natural resources especially forests, vegetation, and wildlife. Hunting and gathering are local way of life for household consumption and selling in local market. The survey results (Table 5) demonstrate that Pua respondents were more confident of community resource access than Na Noi respondents. In total, $44.6 \%$ of Pua respondents assumed that they could manage community resource with government permission, which is more than $\mathrm{Na}$ Noi respondents $(23.2 \%)$. In addition, $37.8 \%$ of Pua respondents viewed that their community rights were legal, which is higher than Na Noi respondents (26.3\%). In addition, $42.5 \%$ of Pua residents considered that their community rights in resource arrangement were irreversible, which is more than Na Noi residents $(12.7 \%)$. The residents of Pua District believed that once the rights of the community are given for resource management, they could not be taken back. Therefore, when the government allowed the community to take care of the community resources, it meant giving the community the opportunity to manage and utilize it according to the established consensus, such as the community consensus on forest use in Pua District.

Table 5. Community rights and food sovereignty dimensions in Na Noi and Pua District, Nan Province.

\begin{tabular}{|c|c|c|c|c|c|c|c|}
\hline \multirow{2}{*}{\multicolumn{2}{|c|}{$\begin{array}{l}\text { Community Rights and } \\
\text { Food Sovereignty }\end{array}$}} & \multicolumn{2}{|c|}{ Na Noi } & \multicolumn{2}{|c|}{ Pua } & \multicolumn{2}{|c|}{ Total } \\
\hline & & Freq. & $\%$ & Freq. & $\%$ & Freq. & $\%$ \\
\hline 1. & \multicolumn{7}{|c|}{$\begin{array}{l}\text { You could manage community resource with the government permission such as } \\
\text { community forest, community deed }\end{array}$} \\
\hline- & No & 103 & 24.2 & 14 & 3.3 & 117 & 27.5 \\
\hline- & Yes & 99 & 23.2 & 190 & 44.6 & 289 & 67.8 \\
\hline- & No reply & 3 & 0.7 & 17 & 4.0 & 20 & 4.7 \\
\hline & total & 205 & 1.48 & 221 & 9.51 & 426 & 0.100 \\
\hline 2. & \multicolumn{7}{|c|}{ Do you think that those arrangements are legal community right? } \\
\hline- & No & 86 & 20.2 & 45 & 10.6 & 131 & 30.8 \\
\hline- & Yes & 112 & 26.3 & 161 & 37.8 & 273 & 64.1 \\
\hline- & No reply & 7 & 1.6 & 15 & 3.5 & 22 & 5.2 \\
\hline & total & 205 & 1.48 & 221 & 9.51 & 426 & 0.100 \\
\hline 3. & \multicolumn{7}{|c|}{ Do you think that the government could take away those rights in the future? } \\
\hline- & Yes & 138 & 32.4 & 24 & 5.6 & 162 & 38.0 \\
\hline- & No & 54 & 12.7 & 181 & 42.5 & 235 & 55.2 \\
\hline- & No reply & 13 & 3.1 & 16 & 3.8 & 29 & 6.8 \\
\hline & total & 205 & 1.48 & 221 & 9.51 & 426 & 0.100 \\
\hline
\end{tabular}




\subsubsection{Chiang Mai Province}

In the areas covered by the Mae Chaem Model and Mae Cham Model Plus projects in Chiang Mai Province, the interview results and focus groups discussions data reveal that Mae Chaem residents regarded the community deed as a governmental declaration supporting local farming for making a living. The community land inheritance rights were considered as a government commitment to not reclaim the land from villagers in the future. Participatory approaches within community forest management provided a new way of life for Mae Chaem residents. The utilization of allocated forest areas provided access to gathering of forest products such as mushrooms, bamboo shoots, and insects for household consumption and local markets. Meanwhile, the government acquired the community mechanism as a way to protect the forest and green area.

\section{Discussion}

\subsection{Land Tenure Security Permits a Food Sovereignty Strategy by Farmers}

In remote rural areas where the majority of the population is in the agricultural sec-tor and the main economic activities are farming, farmers are strongly tied to their land. Land possession provides an opportunity to generate income and food for their own household consumption [24]. In the past, there were three channels to access food, including cultivation, sharing, and hunting and gathering. Food was cultivated and harvested locally, as well as the sharing of food from planting, gathering, and hunting. According to the climate farmers' knowledge of how to access seeds, the crops grown in each area are diverse. Most areas in Northern Thailand are fertile forest areas with many rivers, but the topography of forest lands is typically high and steep, with flat-lands and valleys scattered around [42]. Therefore, Na Noi, Pua, and Mae Chaem, having a mountainous terrain, which is tall and steep, have historically limited human utilization and land tenure $[43,44]$. Over time, first with opium suppression programs and later driven by a growing demand for maize from the global livestock feed industry, integrated farming for household consumption and community trading has undergone a transition to a widespread monocropping for commercial purposes. As a result, farmers have expanded their cultivated land and caused deforestation, even at the risk of arrest and confiscation of their forest land that they encroached upon. In parallel, monoculture has become the mainstream agricultural practice, which requires a large amount of land, especially maize cropping [45]. Therefore, to protect income from illegally cultivated land expansion, farmers have tried to disperse their maize among many plots of land. They have avoided the investment in the land as well, since they do not know if or when the land will be repossessed.

From the land tenure rights aspect, Pua farmers, who possess both fertile land area and legal land deeds, preferred the food sovereignty strategy and mixed strategies. Being the owners of their own land, they have the security to invest in their land. In addition, with both secure land tenure rights and pursuing the food sovereignty strategy, Pua farmers have much less debt.

On the other hand, farmers in Na Noi District and Mae Chaem District preferred the food security strategy or the mixed strategy. Because of lowland land scarcity and lack of legal land deeds, farmers cultivated rice in their own lowland area and other crops in the upland area. They do not invest in the upland area with high-value crops, since they have no tenure rights on those lands, which have greater risk of being confiscated [24]. Additionally, because of the sloping conditions of the uplands, edible crops or high-value crops could not be cultivated. Thus, they concentrated on 'rapid-return on in-vestment' maize monocropping for the livestock feed market.

Moreover, landless farmers in all areas are the most vulnerable. Since they cannot access the lowland area, they mainly rent land in the upland area. Their situations are similar to farmers in Na Noi and Mae Chaem Districts, but they are faced with higher costs for renting land in addition to agricultural inputs. Further, the likelihood of leases being 
cancelled by the landowner is quite high. With land insecurity, landless farmers would not invest in any land and increase their investment in higher market price products.

Land security is not so much about land quantity, as it is about land tenure rights. In the case of Mae Chaem, community deeds and the exchange of deforested area in the high upland for legal community forest areas in lower foothills have increased land security for farmers. With more security of land tenure rights, farmers are willing to make a transition from maize monoculture to integrated farming. After being the owners of the newly redistributed cultivated land, farmers have less fear of land confiscation and are willing to invest more with the high-value crops. They have avoided the food security strategy and preferred the food sovereignty strategy and the mixed strategy instead. We can conclude that land tenure security is a key element for food sovereignty.

\subsection{Food Sovereignty as the Path toward Sustainable Food Security}

Through four channels of food access including cultivation and livestock, gathering and hunting, purchasing, and sharing, sustainable food sovereignty can be achieved (Figure 8). Among the three strategies which farmers have applied to reach food security, the proportion obtained from the different food access channels differed for each strategy as follows:

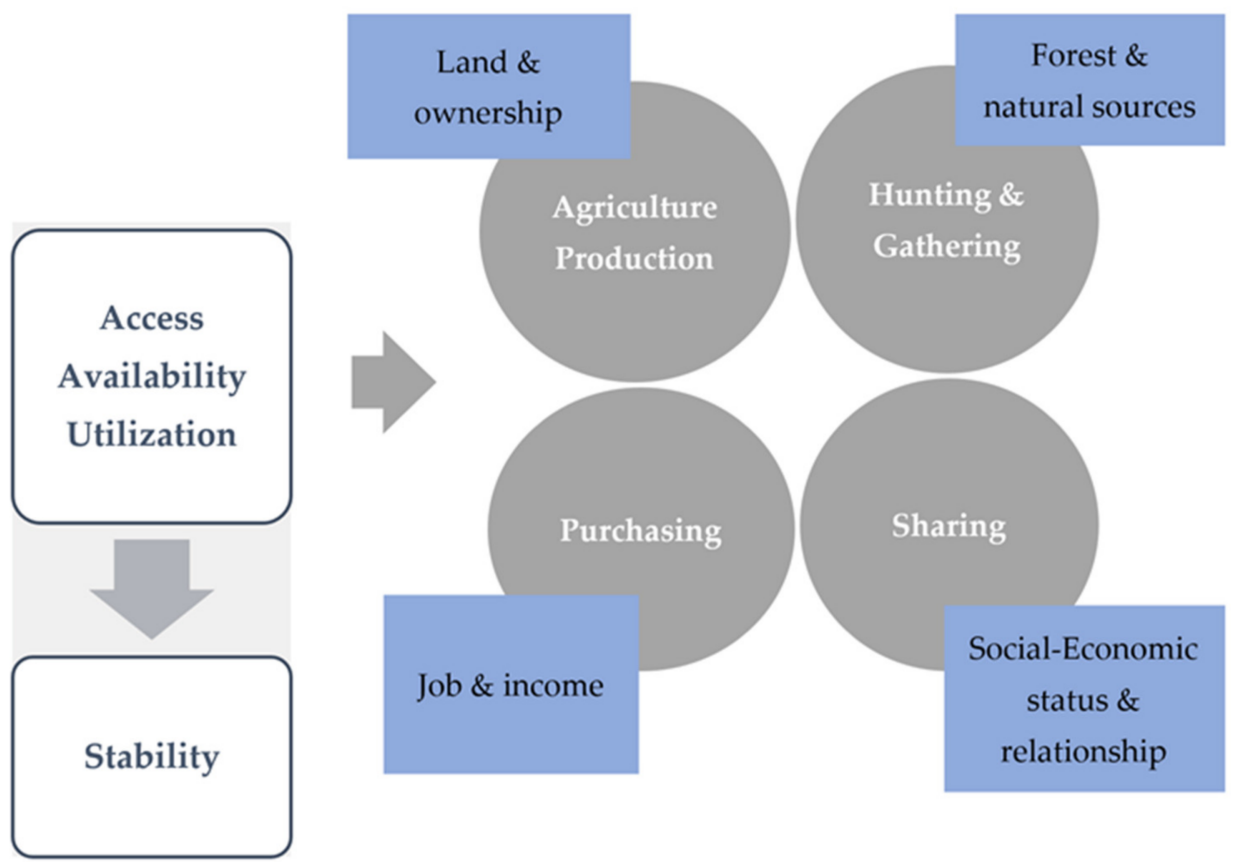

Figure 8. Sustainable food security through four food access channels.

(1) Obtaining food from cultivation and livestock rearing (food sovereignty strategy) is a form of self-provisioning for household consumption and is highly dependent on secure land tenure, as when farmers own their own land. Achieving sustainability means securing farmers' land tenure and ensuring that land rights are not revoked. Generally, this kind of food access occurs in peasant communities, where food crops are cultivated for household consumption. Although, it is a very old way of life, a lot of households still maintain this livelihood with different proportions of food storage. Most of them cultivate rice, not only in Northern Thailand, but in other parts of Thailand as well.

(2) When food is acquired through gathering and hunting (food sovereignty strategy), mostly in forest areas, it means that there are available food resources and rights to access and utilization. This kind of food access depends on the local natural resources, distance from the forest, and skills of food seekers. Therefore, the rights to community re-source management and the forest are a crucial factor. An example is the community forest. When community members are able to gather forest products legally, household livelihoods can 
be sustained. However, they must not destroy the forest ecosystem. By gaining community rights to resource management, the community gains an important local mechanism to protect their resources. In addition, both relationships between humans and nature and between communities and governments would be more harmonious.

(3) Getting food through sharing (food sovereignty strategy) is as old as cultivation and rearing livestock for self-consumption. However, food acquisition by sharing channels differs from self-production, since it is based principally on the relationships between community households, representing generosity. There are two main forms of food sharing. The first one is sharing between individuals, which is an important means of food access in a crisis or difficult situation. It helps to foster food security, not just in rural areas but also in urban family members, especially the food contribution from relatives or the same family, such as sharing rice from the countryside with family members living in the city. Apart from a time of crisis, food sharing among households in the same community is a normal practice for fostering their relationship and social capital as well. The second one is collective sharing such as bringing food to make merit at the temple or organizing activities together. In particular, the temple is considered as an organization dedicated to sharing food among community in the form of merit-making from a religious perspective. This is another form of local social assistance for people in need. Therefore, obtaining food through sharing is a food access channel that arises in a highly interconnected community that believes in sharing [46,47].

(4) Obtaining food from purchasing is the most common channel in the market system (food security strategy). Not only farmers, but also the urban population achieve their food security through this channel. However, this kind of food access channel is determined by the income and economic status of the household. For farmers, applying a food security strategy requires primarily or exclusively producing cash crops such as maize for livestock feed and trading them in the market at a price high enough for purchasing sufficient food. However, their income depends on both the quantity and quality of land as well. Because of the scarcity of good quality lowland area, monoculture expansion has caused deforestation in the uplands. These are global phenomena not only in Thailand. The policyand market-driven induction into commercial cash cropping by peasant farmers drives them into the debt and into forest encroachment.

However, the issue of land security, which is the key enabling factor to achieve food sovereignty and food security from this study, focuses on negotiation to pressure the government to acquire the land tenure rights. Farmers in Mae Chaem District and Na Noi District have a longstanding negotiation between communities and the government to grant the community land tenure rights. The 'community deed' is a pattern that occurs in many areas in Thailand under the restrictions of recent agriculture [48-50]. It is prohibited to sell or transfer to nonfamily members. It implies the rights to manage community resources. Likewise, the community forests provide the opportunity to gather forest products under the community consensus. Thus, building sustainable food security cannot be achieved by the local community alone, but it has to seek support and participation from outside, especially the government, which is never an easy task for peasants. As Blake and co-authors [40] affirm for the same region, these " ... marginalized communities involved in animal feed maize production negotiate with a wide range of external actors. yet the rapid growth of multinational agribusiness corporations within such a context can constrain the voices of local actors, ... ". Those who have been able to obtain some relatively secure form of tenure are thus able to engage in the more secure, in livelihood terms, food sovereignty and mixed strategies.

\section{Conclusions}

We have examined livelihood strategies that peasant families pursue in the context of the explosive expansion of maize monocropping in Northern Thailand to supply the global livestock feed complex. 
The sustainable real food security of rural farmers has a close relationship with land security. When farmers have secure access to land, they can engage in what we have identified as 'food sovereignty' and 'mixed' strategies, which expose them less to potential food and livelihood security crises, including from the risk of indebtedness, that can spiral out of control.

It is not just the amount of land in possession of farmers but also land tenure rights as a guarantee that farmers' land utilization can last for a long time. Then, their cultivation and livestock rearing for either self-consumption and/or for trading in local markets for food can allow for real, sustainable food and livelihood security. In the food sovereignty strategy, families also engage in hunting and gathering which are related with the rights to manage community resources, especially forest. To provide food access throughout the year, apart from land tenure security and resource management rights, government recognition of land rights is very important. Community food-sharing channels that are tied with the community relationship system are another contributing factor. By strengthening community solidarity, local communities are in a better negotiating position regarding the government.

In sum, we have demonstrated the advantages for peasant families of following food sovereignty or mixed strategies rather than the dominant food security strategy. These strategies lead to greater, and more sustainable, real food and livelihood security, with less indebtedness.

Author Contributions: Conceptualization, S.C., C.A. and P.M.R.; data curation, S.C.; formal analysis, S.C. and P.M.R.; methodology, S.C.; writing-original draft, S.C.; writing-review and editing, C.A. and P.M.R. All authors have read and agreed to the published version of the manuscript.

Funding: This research was funded by National Research Council of Thailand grant number 256108A1010001 and Chulalongkorn University. Peter Rosset was invited and funded by Chulalongkorn University Social Research Institute (CUSRI).

Institutional Review Board Statement: Ethical review and approval were waived for this study due to non-existence of the University's Institutional Review Board for social science research prior the project begin in 2019.

Informed Consent Statement: Oral informed consent was obtained from all subjects involved in the study.

Data Availability Statement: Data is contained within the article.

Acknowledgments: We would like to thank Rutsamee Eksiri, Wassana Srijampa, the community members and government officers of Pua, Na-Noi, and Mae-Chaem, CU-Engagement of Chulalongkorn University Project, HuSE and CUSRI.

Conflicts of Interest: The authors declare no conflict of interest. The funders had no role in the design of the study; in the collection, analyses, or interpretation of data; in the writing of the manuscript, or in the decision to publish the results.

\section{References}

1. Ekasingh, B.; Gypmantasiri, P.; Thong-ngam, K.; Grudloyma, P. Maize in Thailand: Production Systems, Constraints, and Research Priorities Benchaphun Ekasingh1 Phrek Gypmantasiri1 Kuson Thong-Ngam1 Pichet Grudloyma2; CIMMYT (International Maize and Wheat Improvement Center): Mexico City, Mexico, 2004.

2. Goss, J.; Burch, D. From Agricultural Modernisation to Agri-Food Globalisation: The Waning of National Development in Thailand. Third World Q. 2001, 22, 969-986. [CrossRef]

3. Bruun, T.B.; de Neergaard, A.; Burup, M.L.; Hepp, C.M.; Larsen, M.N.; Abel, C.; Aumtong, S.; Magid, J.; Mertz, O. Intensification of Upland Agriculture in Thailand: Development or Degradation? Land Degrad. Dev. 2017, 28, 83-94. [CrossRef]

4. Arunrat, N.; Pumijumnong, N.; Sereenonchai, S. Air-Pollutant Emissions from Agricultural Burning in Mae Chaem Basin, Chiang Mai Province, Thailand. Atmosphere 2018, 9, 145. [CrossRef]

5. Woods, K. CP Maize Contract Farming in Shan State, Myanmar: A Regional Case of a Place-Based Corporate Agro-Feed System. Available online: https:/ / www.tni.org/files/download/bicas_working_paper_14_woods.pdf (accessed on 28 June 2021).

6. Chuasuwan, C. Industry Outlook 2018-2020: Frozen and Processed Chicken 2018. Available online: https://www.krungsri.com/ getmedia/1cbe0158-bef8-4d77-aabf-a91f100a47d5/IO_Chicken_181018_EN_EX.pdf.aspx (accessed on 28 June 2021). 
7. Market Research Reports®Inc. World's Top 10 Animal Feed Companies I Market Research Blog. Available online: https: //www.marketresearchreports.com/blog/2019/08/27/world\%E2\%80\%99s-top-10-animal-feed-companies (accessed on 28 June 2021).

8. Chiengkul, P. The Political Economy of the Agri-Food System in Thailand: Hegemony, Counter-Hegemony, and Co-Optation of Oppositions, 8th ed.; Routledge Contemporary Southeast Asia Series; Routledge: New York, NY, USA, 2017; p. 90. ISBN 978-1-315-26792-0.

9. Royal Project Foundation (RPF). Executive Summary. The Royal Project Model: Best Practice Alternative Development Approach for Sustainable Economic, Social, and Environmental Development in the Highlands. 2019. Available online: https://www.hrdi.or.th/en/ public/files/rpfcon/ConferenceInformation/ExecutiveSummaryTheRoyalProjectModel.pdf (accessed on 28 June 2021).

10. Ganjanapan, A. The Politics of Conservation and the Complexity of Local Control of Forests in the Northern Thai Highlands. Mt. Res. Dev. 1998, 18, 71. [CrossRef]

11. Laungaramsri, P. The Ambiguity of "Watershed": The Politics of People and Conservation in Northern Thailand. Sojourn J. Soc. Issues Southeast Asia 2000, 15, 52-75.

12. Sturgeon, J.C. Border Landscapes: The Politics of Akha Land Use in China and Thailand; University of Washington Press: Washington, DC, USA, 2005; ISBN 978-0-295-98544-2.

13. Rakyutidharm, A. Constructing the Meanings of Land Resource and a Community in the Context of Globalization = การสรางความหมายของทรพยากรทดนและชมชนในบรบทโลกาภวตน / Atchara Rakyutidharm. Ph.D. Thesis, Chiang Mai University, Chiang Mai, Thailand, 2009.

14. Delang, C. Deforestation in Northern Thailand: The Result of Hmong Farming Practices or Thai Development Strategies? Soc. Nat. Resour. 2002, 15, 483-501. [CrossRef]

15. Chitbundid, C. The Royally-Initiated Projects: The Making of Royal Hegemony (B.E.2494-2546). Master's Thesis, Thammasat University, Bangkok, Thailand, 2007.

16. Latt, S.; Roth, R. Agrarian Change and Ethnic Politics: Restructuring of Hmong and Shan Labour and Agricultural Production in Northern Thailand. J. Agrar. Chang. 2014, 15. [CrossRef]

17. Clay, E. Food Security: Concepts and Measurement. Trade Reforms and Food Security: Conceptualizing the Linkages; UN Food and Agriculture Organization: Rome, Italy, 2002; pp. 25-34.

18. World Bank. Poverty and Hunger: Issues and Options for Food Security in Developing Countries; World Bank: Washington, DC, USA, 1986.

19. Devereux, S.; Sussex, I. Food Insecurity in Ethiopia: A Discussion Paper for DFID; Institute for Development Studies: Falmer, $\mathrm{UK}, 2000$.

20. Heidhues, F.; Atsain, A.; Nyangito, H.; Padilla, M.; Ghersi, G.; Vallée, J.-C. Development Strategies and Food and Nutrition Security in Africa: An Assessment; International Food Policy Research Institute: Washington, DC, USA, 2004.

21. Food and Agriculture Organization. Rome Declaration on World Food Security and World Food Summit Plan of Action: World Food Summit, 13-17 November 1996, Rome, Italy; FAO: Rome, Italy, 1996.

22. FAO. Declaration of the World Food Summit on Food Security; International Institute for Sustainable Development (IISD): Winnipeg, MB, Canada, 2009; Available online: https://s3.us-west-2.amazonaws.com/enb.iisd.org/archive/download/pdf/ sd/ymbvol150num7e.pdf?X-Amz-Content-Sha256=UNSIGNED-PAYLOAD\&X-Amz-Algorithm=AWS4-HMAC-SHA256\&XAmz-Credential=AKIA6QW3YWTJ6YORWEEL\%2F20210827\%2Fus-west-2\%2Fs3\%2Faws4_request\&X-Amz-Date=20210827 T071734Z\&X-Amz-SignedHeaders=host\&X-Amz-Expires=60\&X-Amz-Signature=0d9e96f47dd0b4ab95b41c8517638a5457ae9 fe23c63c4173c484d87ff62ed5b (accessed on 27 August 2021).

23. Gregory, P.J.; Ingram, J.S.I.; Brklacich, M. Climate Change and Food Security. Philos. Trans. R. Soc. B Biol. Sci. 2005, 360, 2139-2148. [CrossRef] [PubMed]

24. Charoenratana, S.; Shinohara, C. Rural Farmers in an Unequal World: Land Rights and Food Security for Sustainable Well-Being. Land Use Policy 2018, 78, 185-194. [CrossRef]

25. Alpízar, F.; Saborío-Rodríguez, M.; Martínez-Rodríguez, M.R.; Viguera, B.; Vignola, R.; Capitán, T.; Harvey, C.A. Determinants of Food Insecurity among Smallholder Farmer Households in Central America: Recurrent versus Extreme Weather-Driven Events. Reg. Environ. Chang. 2020, 20, 22. [CrossRef]

26. Reincke, K.; Vilvert, E.; Fasse, A.; Graef, F.; Sieber, S.; Lana, M.A. Key Factors Influencing Food Security of Smallholder Farmers in Tanzania and the Role of Cassava as a Strategic Crop. Food Sec. 2018, 10, 911-924. [CrossRef]

27. Antwi-Agyei, P.; Nyantakyi-Frimpong, H. Evidence of Climate Change Coping and Adaptation Practices by Smallholder Farmers in Northern Ghana. Sustainability 2021, 13, 1308. [CrossRef]

28. Jones, P.G.; Thornton, P.K. The Potential Impacts of Climate Change on Maize Production in Africa and Latin America in 2055. Glob. Environ. Chang. 2003, 13, 51-59. [CrossRef]

29. Bunn, C.; Läderach, P.; Ovalle Rivera, O.; Kirschke, D. A Bitter Cup: Climate Change Profile of Global Production of Arabica and Robusta Coffee. Clim. Chang. 2015, 129, 89-101. [CrossRef]

30. Malhi, G.S.; Kaur, M.; Kaushik, P. Impact of Climate Change on Agriculture and Its Mitigation Strategies: A Review. Sustainability 2021, 13, 1318. [CrossRef]

31. Maxwell, D.; Wiebe, K. Land Tenure and Food Security: A Review of Comcepts, Evidence, and Methods; Land Tenure Center, University of Wisconsin-Madison: Madison, WI, USA, 1998. 
32. Holden, S.T.; Ghebru, H. Land Tenure Reforms, Tenure Security and Food Security in Poor Agrarian Economies: Causal Linkages and Research Gaps. Glob. Food Secur. 2016, 10, 21-28. [CrossRef]

33. Rosset, P. Food Sovereignty: Global Rallying Cry of Farmer Movements. Backgrounder 2003, 9, 1-4.

34. Wittman, H.; Desmarais, A.; Wiebe, N. Food Sovereignty: Reconnecting Food, Nature and Community; Food First Book: Oakland, CA, USA, 2010; ISBN 978-0935028379.

35. Martínez-Torres, M.E.; Rosset, P.M. Diálogo de Saberes in La Vía Campesina: Food Sovereignty and Agroecology. J. Peasant. Stud. 2014, 41, 979-997. [CrossRef]

36. Straub, A.; Ronnås, P.; Ronnas, P. Institutions, Livelihoods and the Environment: Change and Response in Mainland Southeast Asia; Nordic Proceedings in Asian Studies; NIAS Press: Copenhagen, Denmark, 2001.

37. Kaewprasert, K.; Nipuna, A. ประวตศาสตรพนททางการเกษตรโหลงปง [Agricultural History of Long Pong Village]; Maechaem Prariyatsuksa School: Chiangmai, Thailand, 2006; pp. 111-140.

38. Ongla, O.; Buddharaksa, W. Mae-Cheam Model: Practices and War of position. J. Soc. Sci. Naresuan Univ. 2020, 16, 21-46.

39. Beaulieu, A.F. Farmers' Responses to Drivers of Forest Cover Change: The Case of Mae Chaem District, Thailand. 2017. Available online: https://ruor.uottawa.ca/bitstream/10393/36890/3/Beaulieu_Antoine_2017_thesis.pdf (accessed on 27 August 2021).

40. Blake, D.J.H.; Thiengburanathum, P.; Thiengburanathum, P.; Friend, R.M.; Doherty, B.; Thankappan, S. Chapter Two-Looking at complex agri-food systems from an actor perspective: The case of Northern Thailand. In Advances in Food Security and Sustainability; Barling, D., Fanzo, J., Eds.; Academic Press: Cambridge, MA, USA, 2019; Volume 4, pp. $33-65$.

41. British Council Newton Fund; University of York; Chiang Mai University. Research Brief: The Mae Chaem Model: A New Blueprint for Sustainable Rural Development in Northern Thailand? 2019. Available online: https://www.york.ac.uk/media/ yesi /yesinew2018/sustainablefood/The \%20Mae\%20Chaem\%20Model-\%20A\%20new\%20blueprint $\% 20$ for $\% 20$ sustainable\%20 rural\%20development\%20in\%20northern\%20Thailand.pdf (accessed on 27 August 2021).

42. Choenkwan, S.; Fox, J.M.; Rambo, A.T. Agriculture in the Mountains of Northeastern Thailand: Current Situation and Prospects for Development. Mt. Res. Dev. 2014, 34, 95-106. [CrossRef]

43. Jarasiunas, G. Assessment of the Agricultural Land under Steep Slope in Lithuania. J. Cent. Eur. Agric. 2016, 17, 176-187. [CrossRef]

44. Leknoi, U.; Likitlersuang, S. Good Practice and Lesson Learned in Promoting Vetiver as Solution for Slope Stabilisation and Erosion Control in Thailand. Land Use Policy 2020, 99, 105008. [CrossRef]

45. Zimmer, H.; Hanh, L.; Lo, D.; Baynes, J.; Nichols, J. Why Do Farmers Still Grow Corn on Steep Slopes in Northwest Vietnam? Agrofor. Syst. 2018, 92, 1721-1735. [CrossRef]

46. Van Esterik, P. Nurturance and reciprocity in Thai studies. In State Power and Culture in Thailand, South East Asian Studies; Monograph 44; Yale University: New Haven, CT, USA, 1996; pp. 22-46.

47. Ebersbach, R. The Principle of Sharing. Segregation and Construction of Social Identities at the Transition from Foraging to Farming. In Studies in Early Near Eastern Production, Subsistence, and Environment 14; Benz, M., Ed.; Ex Oriente: Berlin, Germany, 2010; pp. 159-182.

48. Ahlquist, D. Losing Place in The Corn Mountains: Forest Conservation, In Situ Displacement \& Agrarian Transformation in Upland Northern Thailand. Ph.D. Thesis, Cornell University, New York, NY, USA, 2015.

49. Hunsberger, C.; Corbera, E.; Borras, S.M.; Franco, J.C.; Woods, K.; Work, C.; De La Rosa, R.; Eang, V.; Herre, R.; Kham, S.S.; et al. Climate change mitigation, land grabbing and conflict: Towards a landscape-based and collaborative action research agenda. Can. J. Dev. Stud. 2017, 38, 305-324. [CrossRef]

50. Wittayapak, C. History and geography of identifications related to resource conflicts and ethnic violence in Northern Thailand. Asia Pac. Viewp. 2008, 49, 111-127. [CrossRef] 